\title{
FINANCIAL CAPITAL: ACCOUNTING PROCEDURES AND RESPECTIVE COMMENTS
}
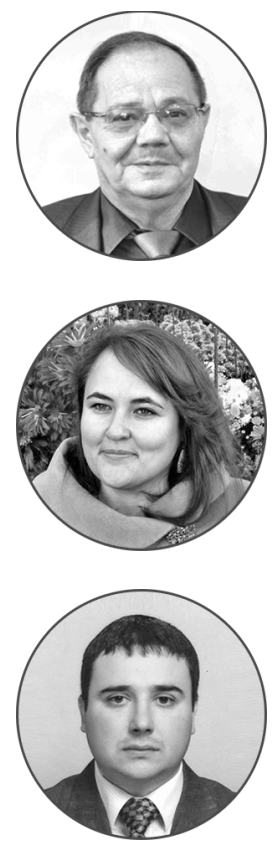

\section{Article history:}

Received 14 June 2018

Received in revised form 24 July 2018

Accepted 30 July 2018

Translated 13 September 2018

Available online 28 September 2018

JEL classification: M40, M41

Keywords: business accounting, integrated reporting, model, stock value, financial asset, monetary assets and liabilities, cash resources capitalization, accounting procedures

\author{
Viktor S. PLOTNIKOV \\ Novosibirsk State University of Economics and Management (NSUEM), Novosibirsk, Russian Federation \\ vcplotnikov@yandex.ru \\ https://orcid.org/0000-0001-7214-1847 \\ Corresponding author
}

\section{Olesya V. PLOTNIKOVA}

Novosibirsk State University of Economics and Management (NSUEM), Novosibirsk, Russian Federation vcplotnikov@yandex.ru https://orcid.org/0000-0002-2384-6418

\section{Mikhail V. BEZHAN}

Plekhanov Russian University of Economics (PRUE), Sevastopol Branch, Sevastopol, Russian Federation mm180883@mail.ru https://orcid.org/0000-0002-1570-1091

\begin{abstract}
Importance In this research, we formulate a body of theoretical and conceptual principles for the business accounting model, which would make the general set of benchmarks to recognize and carry items of financial capital stocks in integrated reporting.

Objectives It is reasonable to use the concept for maintaining the financial capital during its conversion into other types of capital. This provision of the business accounting model is based on specific accounting procedures for recognizing the creation of the financial capital value and its conversion and accompanied with respective comments.

Methods The methodology rests on general theories of positive and normative economics and general methods of observation, abstraction, deduction and induction, statistical and fact analysis of economic phenomena.

Results As a result of the research, we qualify financial assets, cash, equity instruments of the other entity and contractual rights as items of financial capital. They mainly determine its value. Goodwill is a part of the value of long-term financial instruments, rather than an intangible asset. Changes in its value signify the impairment of other assets, investee's assets. Accounts receivables shows the monetized portion of the financial capital value.

Conclusions and Relevance To illustrate the result of the research, we perform accounting procedures by consecutively recognizing entries for forming the financial capital stock in the business accounting model and determining specific techniques - monetization of financial capital metrics and capitalization of cash which form and change the value of certain items of financial capital.
\end{abstract}


Nowadays there are numerous definitions of accounting as authors attempt to supplement, specify and even alter the concept of accounting as an economic science. This article is not another guess concerning some aspects that could be integrated or specified, thereby making the accounting discipline more orderly or substantial. According to M.R. Mathews and M.H.B. Perera, the theory has not its own content as a language. It is virtually a combination of tautology. It is meant to be a system (like a catalog) to organize empirical data and make them understandable. It should be viewed through respective criteria [1, p. 209].

The accounting theory originated from some biased constructs in business operations. Its mechanisms should not only be described, but also recognized and clarified. Moreover, accounting concepts should formulate what general ideas are to be verified and scrutinized [2, p. 10].

E.S. Hendriksen and M.F. Van Breda define the accounting theory as a coherent set of hypothetical, conceptual and pragmatic principles that constitute a general frame of reference to investigate the nature of accounting. Thus, the main purpose of accounting is to infer a set of logically consistent principles, which lay the basis for evaluating and developing the accounting practice ${ }^{1}$.

This definition of accounting theory is quite compliant with the methodology of positive economics: Viewed as a body of substantive hypotheses, theory is to be judged by its predictive power for the class of phenomena which it is intended to 'explain' [3, p. 183].

Referring to the above views, let us consider new trends in the development of accounting, i.e. business accounting method and balance sheet generalization method, and characterize it. Making this hypothesis, we should provide the rationale for introducing fundamental concepts of the integrated

${ }^{\dagger}$ For the source article, please refer to: Плотников В.С., Плотникова О.В., Бежан М.В. Финансовый капитал: бухгалтерские процедуры и комментарии к ним. Международный бухгалтерский учет. 2018. Т. 21. № 8. C. 887-903.

URL: https://doi.org/10.24891/ia.21.8.887

${ }^{1}$ Mathews M.R., Perera M.H.B. Teoriya bukhgalterskogo ucheta [Accounting Theory and Development]. Moscow, Audit, YUNITI Publ., 1999, p. 95. reporting framework into the accounting theory. They would substantially enrich it since different types of capital are concerned (financial, manufactured, intellectual, etc.) as corporate assets used in the value creation process in the short, mid and long run.

The hypothesis may be founded on the definition of the business accounting model as put by V.S. Plotnikov and O.V. Plotnikova: Business accounting is a data set of the business model reflecting the value creation process and value increment, changes in corporate performance. The data set should draw on the information on estimated and factual stock of capitals, which feed or contribute to value creation processes. They are quantified as monetary liabilities, financially supporting the conversion of monetary assets into business facts in the short, mid and long run. The comprehensive result of such conversion should be recognized in integrated reporting ${ }^{2}$ [4, p. 14].

However, we believe it is worth specifying some aspects of this definition. Business accounting constitutes a data model of continuing improvement of corporate value creation and building, which is based on the recognition of estimated and factual stock of different types of capital (financial, manufactured, human, intellectual, social, natural, etc.) driving the value creation processes in the short, mid and long run. It employs financial and non-financial information stakeholders take into consideration for business appraisal purposes.

Furthermore, the definition of the business accounting model should clarify the meaning of the information on estimated and factual stock of capitals. It first concerns capitals qualified as assets, rather than liabilities of the balance sheet theory, such as financial, manufactured, customer, intellectual capital, etc. Unfortunately, such types of capital are not regarded as accounting items in the Conceptual Framework for Financial Reporting. Thus, to avoid any misunderstanding, it is reasonable to explicitly state that estimates underlying

\footnotetext{
${ }^{2}$ The definition proceeds from the article by Plotnikov V.S., Plotnikova O.V. [Philosophy of Accounting as an Economic Science]. Uchet. Analiz. Audit = Accounting. Analysis. Auditing, 2017, no. 3, pp. 7-21. URL: https://cyberleninka.ru/article/v/filosofiya-buhgalterskogo-uchetakak-ekonomicheskoy-nauki (In Russ.). The authors clarified the definition.
} 
the hypothesis verification should not necessarily be phenomena which have not yet happened. Hence, they should not unavoidably predict the future events. They may be evidence of the past events, which have not been investigated yet or unknown to a forecaster [1, p. 217].

M. Friedman and L.J. Savage's methodological views basically give a methodological hint for explaining how those capitals, which ultimately underlie the business value or its business models, should be recognized in business accounting.

Recognizing the stock value of certain capitals under the International Integrated Reporting Framework, we should bear in mind three key characteristics of assets as mentioned in the Conceptual Framework for Financial Reporting and used to identify assets.

1. It embodies the probable future benefit arising from an ability to directly or indirectly trigger an increment in cash (or in combination with other assets).

2. It helps a business entity derive profit or manage it by other means.

3. Business operations or other events boosting the entitlement for a benefit or control over its have already taken place ${ }^{3}$.

Adhering to these indispensable characteristics of assets, we attempt to coordinate it with the concept of stock and cash flows as stated in the International Integrated Reporting Framework:

The capitals are stocks of value that increases, decreases or transforms through activities and outputs of the organization ${ }^{4}$. Unfolding the subject of this research, we focus on the concept of financial capital and those relevant accounting procedures that help recognize the formation of stock of its value and use it for transforming stock of financial capital into stock of other capitals.

\footnotetext{
${ }^{3}$ Hendriksen E.S., Van Breda M.F. Teoriya bukhgalterskogo ucheta [Accounting Theory]. Moscow, Finansy i Statistika Publ., 1997, p. 287.

${ }^{4}$ International Integrated Reporting Framework, paragraph 2.11. URL: http://integratedreporting.org/wp-content/uploads/2015/03/13-1208-THE-INTERNATIONAL-IR-FRAMEWORK-2-1.pdf

International Integrated Reporting Standard. URL: http://integratedreporting.org/wp-content/uploads/2015/03/13-12-08THE-INTERNATIONAL-IR-FRAMEWORK-2-1.pdf
}

We also respect the definition of accounting procedure given by Ya.V. Sokolov: An accounting procedure represents a series of accounting tasks that are addressed by qualifying facts of business operations, that is, recording, grouping and interpreting (analysis). The procedure is designated for decision making [5, p. 47].

So, financial capital is the pool of funds that is:

- available to an organization for use in the production of goods or the provision of services;

- obtained through financing, such as debt, equity or grants, or generated through operations or investments ${ }^{5}$.

However, before financial capital is recognized as the pool of funds, its definition should be compared with the three characteristics of assets. As per IAS 32 - Financial Instruments: Recognition and Measurements, the concepts of financial capital and financial assets are collated. So, financial asset is any asset that is:

1) cash;

2) an equity instrument of another entity;

3) a contractual right ${ }^{6}$.

Cash flow is the principle component of stock of financial capital, which is employed for the following purpose. Investment decision making results from investment planning. It is mainly made of expenditures (reduction in monetary funds) and receipts (increase in monetary funds), i.e. cash flows reflecting streams of payments. Financial planning also involves such concepts as expenditures and receipts in terms of the current corporate solvency $[6$, p. 1].

It goes without saying that the main volume of monetary funds is the backbone of business operations for creating value in the short, mid and long run.

\footnotetext{
${ }^{5}$ International Integrated Reporting Standard, paragraph 2.15. URL: http://integratedreporting.org/wp-content/uploads/2015/03/13-1208-THE-INTERNATIONAL-IR-FRAMEWORK-2-1.pdf

${ }^{6}$ Primenenie MSFO: $v$ trekh chastyakh [International GAAP: Generally Accepted Accounting Practice under International Financial Reporting Standards]. Moscow, Al'pina Pablisher Publ., 2016, p. 681
} 
In the mean time, financial assets of monetary funds, that companies handle, are of short-term nature, marketable and exposed to low risk, being in continuous circulation. Therefore, monetary funds constitute the main component of financial capital recognized as an asset. They can hardly be qualified as the stock of funds since it means that the funds are temporarily withdrawn from the circulation, that is, operating activity. The stock value of monetary funds shows the level of corporate solvency.

Some difference is observed in considering the issue of recognizing equity instruments of the other entity as the stock value of financial capital. The financial assets constitute financial contributions (investments) to the other entity in order to derive variable income in the future. To have power over an investee, an investor must have existing rights that give it the current ability to direct the relevant activities. For the purpose of assessing the power, only substantive rights and rights that are not protective shall be considered ${ }^{7}$. Such financial assets represented with common stocks or other financial instruments of the other entity can be recognized as the stock of financial capital.

The recognition and valuation of financial capital items as part of the business accounting model are scrutinized in the following parts of this article. To substantiate the concept of financial capital at this step, let us focus on another economic concept of the benefit-cost ratio. Choosing the concept of the benefit-cost ratio, it is reasonable to consider how it is transformed in the business accounting model since it, too, concerns the verification of the accounting theory, meaning that each approach to construing the accounting theory requires methods to prove $i^{8}$. This is a very appropriate and accurate definition of the theoretical verification. However, we would like to specify it. Each accounting concept needs to be verified in order to determine its significance and status in the accounting theory, reveal the substance of accounting items and set the practical development course of accounting.

\footnotetext{
${ }^{7}$ International Financial Reporting Standard 10 - Consolidated Financial Statement [IFRS 10:B9]: Order of the RF Ministry of Finance of December 28, 2015 № 217H. (Edition of June 27, 2016).

${ }^{8}$ Hendriksen E.S., Van Breda M.F. Teoriya bukhgalterskogo ucheta [Accounting Theory]. Moscow, Finansy i Statistika Publ., 1997, p. 134.
}

As for probable future benefits, IFRS 10 Consolidated Financial Statements provides the following definition: An investor controls an investee when the investor is exposed, or has rights, to variable returns from its involvement with the investee and has the ability to affect those returns through its power over the investee 9 .

In fact, these characteristics are enough to recognize equity instruments of the other entity as an item of financial capital qualified as a corporate asset. What else should be done is to add the third characteristic: investment (long-term financial contributions) have already made to gain the control over the investee.

However, we need to address two more issues to devise the business accounting model of financial contribution. The issues concern the financial capital. What is goodwill? Is it a part of investment? Shall short-term financial investment be qualified as assets?

Addressing the first issues, we should remember that goodwill is inseparable from the business valuation. That is why it is a non-identifiable asset. The future benefit from such an asset can hardly be estimated. Does it make any sense in estimating the economic benefit from a non-identifiable asset, indeed? Thus, it is rather difficult to give any logic explanation when linking its derecognized value with any income.

Nevertheless, goodwill is an asset. It is not intangible as authors and legislature try to label it but rather an asset, the value of which was formed when the investor acquires the control over investees, being an integral part of the price, which is usually quoted in the stock market.

The crucial moment we would like to point out is that goodwill solely results from the valuation of other assets. We mean assets controlled by the acquiring party when it made financial investment in the investee (subsidiary) [7, p. 147].

It is noteworthy that goodwill is the difference between the purchase price and historical cost of all assets and liabilities, i.e. net assets of the investee.

\footnotetext{
${ }^{9}$ International Financial Reporting Standard 10 - Consolidated Financial Statement [IFRS 10:6]: Order of the RF Ministry of Finance of December 28, 2015 № 217H. (Edition of June 27, 2016).
} 
The fact that the value of financial investment is split into financial investment matching the carrying value of the investee's net assets and goodwill value is mandatory and compliant with IFRS 10 Consolidated Financial Statements ${ }^{10}$. Consolidated financial statements present performance results of a consolidated group of entities as a single unit. However, it should be excluded from the consolidated balance of the investee's net assets at the respective value of the investor's financial contributions. Hence, the value of goodwill shall be left only in the consolidated balance sheet out of the entire pool of long-term investment, while transforming the value of the parent's long-term investment into assets and liabilities of the subsidiary, which are added to the value of the parent's assets and liabilities.

Before reviewing other items of the stock value of financial capital, it is necessary to analyze the financial capital through the balance scorecard of the integrated balance sheet in terms of the balance sheet theory. For this purpose, accounting procedures shall be performed explaining the sequence of accounting tasks to be addressed.

Accounts procedures are based on the equation

$A=L$,

where $A$ is a set called asset,

$L$ is a set called liability. The denotations are nominal and can be transposed.

As mentioned above, the sets can be decreased or increased but it is solely germane to the structure of each set. Changes in the scope of both sets is modification, while the changes in the structure of a set is permutation.

Every action and/or event reshapes an item of one and/or both sets ( $A$ and $L$ ) because items of the sets are represented with situational facts.

So, if every action and/or event modifies the sets, then

$$
\begin{aligned}
& A+a=L+a \\
& \text { or } A-b=L-b,
\end{aligned}
$$

where $a$ is a business fact increasing both sets,

\footnotetext{
${ }^{10}$ Ibid.
}

$b$ is a business fact decreasing both sets.

If an action or even rearrange only the structure of one of the sets, two permutation scenarios are possible:

$$
\begin{aligned}
& A=c+c=L, \\
& A=L+d-d .
\end{aligned}
$$

The four situations, which A.M. Galagan $[8, p$. 228]called four types, has a serious impact on the overall accounting theory of the 20th century [5, p. 258]. Notwithstanding all possible arguments about the role and importance of double entry, its significance is hard to negate. Handling the four situations when the balance shifts, we are going to set a model to account for long-term investment made in order to gain the control over an investee, and recognize the result of accounting procedures in the integrated balance sheet.

Bearing in mind the provision of the International Integrated Reporting Framework stating that the primary purpose of an integrated report is to explain to providers of financial capital how an organization creates value over time ${ }^{11}$. It should be noted that providers of financial capital seek for the information about methods the entity intends to use in order to create value. In this case, it concerns the value of business combinations and what resources may be needed.

The International Integrated Reporting Framework provides the definition of information to be presented in the integrated report so as to evaluate the entity's items generating or being capable of generating value, i.e. showing the entity's ability to create value in the future. To solve the issue, the concept of constructive (contractual) obligation should be involved: like business facts, the obligation and obligatory right are within the scope of accounting practices and determined with elementary moments of the financial and business process, which reinforces or rearranges the financial position of an entity as part of the balance sheet generalization [9, p. 122].

The concept of constructive obligation, or contractual obligation, which is more

\footnotetext{
${ }^{11}$ International Integrated Reporting Framework. URL: http://integratedreporting.org/wp-content/uploads/2015/03/13-12-08THE-INTERNATIONAL-IR-FRAMEWORK-2-1.pdf
}

Please cite this article as: Plotnikov V.S., Plotnikova O.V., Bezhan M.V. Financial Capital: Accounting Procedures and Respective Comments. Digest Finance, 2018, vol. 23, iss. 3, pp. 243-253. 
understandable for accountants, implies that the balance sheet shall indicate the desired result of the obligations assumed by parties to an exchange deal. That is, it means forecasting the fact of an exchange deal (conclusion of a contract), which has not occurred yet [2, p. 7].

If used in the business accounting model, the concept of constructive obligation helps mark the future business combination resources within the body of accounts for monetary assets and liabilities. In this case, the legal design of the agency relations, as an analytical concept, plays an important role in the contemporary institutional theory [10, p. 32].

To introduce long-term investment into the business accounting model or even a working chart of accounts, we should add accounts of monetary assets and liabilities. Monetary assets constitute contractual rights of the buyer for an asset but stated as a fixed amount of money for the item to be delivered in the future [11, p. 54].

Intended to gain the control over the investee, longterm investment is formalized as respective contracts in the stock exchange. Such contracts include a call option implying the buyer's contractual right: $A$ call option gives the holder the right to buy the underlying asset by a certain date for a certain price [12, p. 44].

A call option confers the buyer's right, rather that an obligation, to make a business combination deal. Therefore, as per IAS 32 - Financial Instruments: Presentation, such contracts can be qualified as financial assets. Furthermore, a call option is an item traded on the stock exchange, the value of which is in sync with market conditions. The value of an underlying asset, i.e. common stocks, remains unchanged before the deal is completed or concluded. Hence, the value of an equity instrument of the other entity, as a financial asset, will be expressed as an algebraic sum of the value of common stocks and value of the call option. In the mean time, monetary liabilities constitute contractual obligations to pay the amount stipulated in the contract, notwithstanding the behavior of the asset price and monetary item in the financial market [11, p. 57].
Monetary liability reflects that the holder of the call option intends to pay for the buyer's stocks (holder of the put option) in the future, rather than the factual payment for them. That is why accounts of monetary assets and liabilities may help report accounting procedures for the business combination deal.

Assume that the total value of the business combination deal, which confers the control over the investee, is RUB 500,000 (including RUB 100,000 in the value of the call option). Thus, purchasing a call option on the stock exchange, Entity $A$ should recognize its right to buy common stocks of Entity $B$ in the following manner:

\section{Debit Monetary Assets, Subaccount Call Option RUB 500,000. \\ Credit Monetary Liabilities, Subaccount Put Option RUB 500,000.}

Comment: Call and put options empower their holders to perform a certain action, that is Entity $A^{\prime} s$ right to buy common stocks of Entity B, and Entity B's right to sell its stocks, but not binding them with obligations to do so. This distinguishes the accounting procedure for monetization of contractual provision from the recognition of the business fact that has already taken place, i.e. the purchase of Entity B's stocks.

Moreover, declaring its intention to buy Entity B's stocks, Entity A acquires a put option, which it is to pay immediately on the stock exchange as much as RUB 100,000. The value is included into the total value of Entity A's financial contributions but Entity $A$ recognizes that the market value of Entity $B$ exceeds their carrying amount as of the acquisition date of the call option:

Debit Monetary Assets, Subaccount Put Option RUB 100,000.

Credit Financial Capital, Subaccount Monetary Funds RUB 100,000.

Comment: This accounting procedure indicates that the payment was made for Entity B's put option that implies Entity A's right to purchase common stocks of Entity B.

Concurrently, monetary assets convert into an item of Entity A's financial capital - goodwill. 
Debit Financial Capital, Subaccount Goodwill

RUB 100,000.

Credit Monetary Assets, Subaccount Put Option RUB 100,000.

Comment: So, goodwill, a new item of financial capital, is accrued in business accounting. It is an item of financial capital unlike an intangible asset item, which it usually pertains to.

The next step of the business combination deal takes place on the option expiration date, i.e. the date when the terms of the deal become irrevocable.

Debit Account 62 Settlements with Buyers and Customers RUB 400,000.

Credit Monetary Assets, Subaccount Call Option RUB 400,000.

Comment: In fact, at the second step, the accounting procedure shows how Monetary Assets - Subaccount Call Option converts into the other monetary asset accounts receivable, which is carried within amounts due. Whereas the transferring person concedes the right to control the economic income represented with accounts receivable ${ }^{12}$. Moreover, a call option empowers its holder to obtain common stocks. As formulated by E.S. Hendriksen and M.F. Van Breda, the right to control cannot be denied if the transferring party has the ability to resell accounts receivable ${ }^{13}$.

At the third step of accounting for the business combination deal, the entity reports business facts in relation to its monetary accounts.

Debit Account 58 Financial Contributions, Subaccount Common Stocks RUB 400,000.

Credit Account 62 Settlements with Buyers and Customers RUB 400,000.

Comment: In fact, this accounting procedure reports the substitution of a monetary indicator with accounts receivable for obtaining Entity B's common stocks worth RUB 400,000.

\footnotetext{
${ }^{12}$ Hendriksen E.S., Van Breda M.F. Teoriya bukhgalterskogo ucheta [Accounting Theory]. Moscow, Finansy i Statistika Publ., 1997, p. 352.

${ }^{13}$ Ibid.
}

However, the account Monetary Liabilities is left unrecognized in accounting records. It means that Entity $A$ is to pay for stocks of Entity $B$ as much as RUB 400,000 in monetary funds.

Debit Monetary Liabilities, Subaccount Put Option $R \cup B$ 400,000.

Credit Financial Capital, Subaccount Monetary Funds $R \cup B$ 400,000.

Comment: In fact, the six accounting procedures are confined to the substitution of an item of financial assets - monetary assets - with the other one (equity instruments of the other entity).

As per the International Integrated Reporting Framework, financial capital is regarded as a provision. So, in this case, it is considered as the provision of monetary funds, which is constrained with the amount of retained earnings, which the entity gained, and cash flows reallocated to the provision of financial capital earmarked for the business combination deal. The item Retained Earnings remains unchanged, but the entity is prohibited to use the monetary funds for other purposes whatsoever. For this particular reason, financial capital should be treated as the provision of funds.

However, the accounting procedures are not over even after the transformation of some items of financial capital into the other ones of the business combination deal are recognized. Financial capital undergoes the most crucial rearrangements to fit in the production capital when financial statements of a subsidiary are included into the consolidation perimeter of entities since the financial reporting entity identifies which subsidiaries', joint ventures' and associates' transactions and related evens are included in the organization's financial report. The financial reporting entity is determined according to applicable financial reporting standards which revolve around the concepts of control or significant influence ${ }^{14}$.

We should add that net assets of the subsidiary and respective percentage of the parent's financial

\footnotetext{
${ }^{14}$ International Integrated Reporting Framework, paragraph 3.33. URL: http://integratedreporting.org/wp-content/uploads/2015/03/13-1208-THE-INTERNATIONAL-IR-FRAMEWORK-2-1.pdf
}

Please cite this article as: Plotnikov V.S., Plotnikova O.V., Bezhan M.V. Financial Capital: Accounting Procedures and Respective Comments. Digest Finance, 2018, vol. 23, iss. 3, pp. 243-253. https://doi.org/10.24891/df.23.3.243 
investment are excluded out of the consolidated financial statements. Therefore, the parent's financial capital used to gain the control over the subsidiary is converted into the pool of assets and liabilities in the consolidated financial statements.

The underlying theory of the group formation underlies what method will be chosen to evaluate the effectiveness of the holding group incorporation $[13$, p. 77]. Thus, IFRS 3 - Business Combinations emphasizes that accountants should apply the acquisition method or method for the full integration of accounts as the main technique to recognize the control over the investee. IFRS 3 thereby positions the control acquisition method as a tool to include a subsidiary into the consolidation perimeter [14, p. 146].

Financial capital is transformed in the most interesting way in consolidated accounting and consolidated financial reporting. As required by one of the specific accounting techniques, stocks purchased from the subsidiaries' shareholders are recognized in the balance sheet of the parent entity at the acquisition cost, while the share in the subsidiary's equity is recorded at the carrying amount of the injected assets [15, p. 11].

It should be kept in mind that when preparing consolidated financial statements, the value of the parent's financial investment should correlate with the share in the subsidiary's equity. Both values shall be excluded from the consolidated financial statements.

Comment: As we mentioned, the value of the parent's financial investment (net of the value of the option) is RUB 400,000. At the same time, the value of the subsidiary's net assets is RUB 300,000 as of the expiration date of the option. Therefore, this is financial investment worth RUB 350,000 that should be eliminated from the consolidated financial statements.

Debit 80 Share Capital

Account 82 Reserve Capital

Account 84 Retained Earnings
Credit Financial Capital, Subaccount Financial Investment RUB 350,000 ${ }^{15}$.

In this case, two questions are pending. How should RUB 50,000 in the remaining part of financial investment be treated? (RUB 400,000 - RUB $350,000)$ ? To answer the question, let us refer to the following consolidated accounting rule: The positive difference between the offering price (the value of stocks offered as a means of payment or the value of the contributed property) and the value of the subsidiary's net assets is capitalized, being treated as the positive goodwill in consolidation and recorded within intangible assets [15, p. 12], So, the following accounting procedure should be performed:

Debit Financial Capital, Subaccount Goodwill RUB 50,000.

\section{Credit Financial Capital, Subaccount Financial} Investment RUB 50,000.

The second question is much more difficult to answer. Which type of the financial capital transformation is it, if financial capital is eliminated from consolidated financial statements? There are three reference criteria:

- title;

- control over the investee;

- power.

They determine the purpose and structure of the investee. Analyzing the investee's structure, a special focus is put on the adequacy of equity instruments for controlling the investee, which confer the commensurate number of voting rights to the holder through common stocks of the investee.

In the given example, the investor (Parent Entity A) invests RUB 400,000, i.e. redeems Entity B's net assets worth RUB 350,000 as of the consolidation date of entities.

RUB 200,000.

$R \cup B 50,000$.

$R \cup B 100,000$.

\footnotetext{
${ }^{15}$ For more detailed comments on the accounting procedures, please refer to Plotnikov V.S., Plotnikova O.V. Ob"edinenie biznesa $i$ konsolidirivannaya finansovaya otchetnost': monografiya [Business combinations and consolidated financial statements: a monograph]. Moscow, INFRA-M Publ., 2018, 278 p. URL:

www.dx.doi.org/10.12737/monography_5aafadaa5e5677.15904893
} 
Doing so, the investor (Entity A) gains the total control over the investee's assets, thereby assuming all the obligations of the subsidiary. IFRS 10 Consolidated Financial Statements indicates that (a) consolidated financial statements combine like items of assets, liabilities, equity, income, expenses and cash flows of the parent with those of its subsidiaries ${ }^{16}$.

Comment: Hence, in the consolidated financial statements, the parent's financial investment (financial capital) is transformed (in line with the share) into assets and liabilities of the subsidiary, which are merged with those of the parent.

Furthermore, it is important and even reasonable to treat financial capital as the provision of funds only in short-term periods (less than a year). Thus, it will be indicative of the real stock value of financial capital earmarked for the reporting period. Such financial capital models have been employed already in the business accounting and analysis model.
However, the provision of funds - the amount of monetary funds at the certain point of time - should be made in line with a quick capitalization of monetary funds into the stock value of other capital or for ensuring the control over the investee or significant influence on it, etc. When an entity makes the substantial provision of monetary funds, which it absorbed from financial investment of other investors or loans for the future plans, the monetary funds are basically immobilized, or withdrawn from the circulation, thereby affecting the value creation process in the short and even mid run. It is absolutely unacceptable to make the provision of monetary funds for a long-term period. Therefore, what the business accounting model pursues is to monetize indicators of monetary funds, which are not indicative of the real figures, but rather estimate them. In this case, indicators of monetary assets may be used since they show the stock value that monetary funds should have in the future (in the mid and long run).

\footnotetext{
${ }^{16}$ International Financial Reporting Standard 10 - Consolidated Financial Statement [IFRS 10:B86]: Order of the RF Ministry of Finance of December 28, 2015 № 217H. (Edition of June 27, 2016).
}

Please cite this article as: Plotnikov V.S., Plotnikova O.V., Bezhan M.V. Financial Capital: Accounting Procedures and Respective Comments. Digest Finance, 2018, vol. 23, iss. 3, pp. 243-253. 


\section{References}

1. Friedman M., Savage L.J. Analiz poleznosti pri vybore sredi al'ternativ, predpolagayushchikh risk. $V$ kn.: Teoriya potrebitel'skogo povedeniya i sprosa [The Utility Analysis of Choices Involving Risk. In: The Theory of Consumer Behavior and Demand]. St. Petersburg, Ekonomicheskaya shkola Publ., 1993, pp. 209-230.

2. Plotnikov V.S., Plotnikova O.V. [Philosophy of accounting as an economic science (Part 1)]. Uchet. Analiz. Audit $=$ Accounting. Analysis. Auditing, 2017, no. 2, pp. 7-17. URL:

https://cyberleninka.ru/article/n/filosofiya-buhgalterskogo-ucheta-kak-ekonomicheskoy-nauki-chast-1 (In Russ.)

3. Hausman D.M. (Ed.) Filosofiya ekonomiki. Antologiya [The Philosophy of Economics: An Anthology]. Moscow, Gaidar Institute Publ., 2012, 520 p.

4. Plotnikov V.S., Plotnikova O.V. [Philosophy of Accounting as an Economic Science]. Uchet. Analiz. Audit $=$ Accounting. Analysis. Auditing, 2017, no. 3, pp. 7-21.

URL: https://cyberleninka.ru/article/n/filosofiya-buhgalterskogo-ucheta-kak-ekonomicheskoy-nauki (In Russ.)

5. Sokolov Ya.V. Osnovy teorii bukhgalterskogo ucheta [Fundamentals of accounting theory]. Moscow, Finansy i statistika Publ., 2000, 496 p.

6. Baetge J. Balansovedenie [Bilanzen]. Moscow, Bukhgalterskii uchet Publ., 2000, 454 p.

7. Plotnikov V.S., Plotnikova O.V. [Goodwill as a capitalization of transaction costs of a business combination]. Ekonomicheskii analiz: teoriya i praktika = Economic Analysis: Theory and Practice, 2017, vol. 16, iss. 1, pp. 145-159. (In Russ.) URL: https://doi.org/10.24891/ea.16.1.145

8. Galagan A.M. Osnovy obshchego schetovedeniya [Basics of general accounting]. Moscow, Narkomtorg SSSR i RSFSR Publ., 1928, 436 p.

9. Plotnikov V.S., Plotnikova O.V. [The concept of positive accounting obligations]. Mezhdunarodnyi bukhgalterskii uchet = International Accounting, 2013, vol. 16, iss. 23, pp. 9-17. (In Russ.)

10. Furubotn E.G., Richter R. Instituty i ekonomicheskaya teoriya: Dostizheniya novoi institutsional'noi ekonomicheskoi teorii [Institutions and Economic Theory: The Contribution of the New Institutional Economics]. St. Petersburg, St. Petersburg State University Publ., 2005, 702 p.

11. Plotnikov V.S., Plotnikova O.V. [In the conceptual basis of accounting]. Auditor, 2014, no. 9, pp. 52-61. URL: http://xn----7sbbaj7auwnffhk.xn--p1ai/article/4576 (In Russ.)

12. Hull J.C. Optsiony, f'yuchersy i drugie proizvodnye finansovye instrumenty [Options, Futures, and Other Derivatives]. Moscow, Vil'yams Publ., 2008, 1024 p.

13. Yakutin Yu. [Conceptual approaches to the evaluation of the effectiveness of corporate integration]. Rossiiskii ekonomicheskii zhurnal = Russian Economic Journal, 1998, no. 6, pp. 71-81. (In Russ.)

14. Plotnikov V.S., Plotnikova O.V. Ob"edinenie biznesa i konsolidirovannaya finansovaya otchetnost': monografiya [Business combination and consolidated financial statements: a monograph]. Moscow, INFRA-M Publ., 2018, 278 p. URL: https://doi.org/10.12737/monography_5aafadaa5e5677.15904893 
15. Plotnikov V.S., Plotnikova O.V., Bezhan M.V., Mel'nikov V.I. [Conceptual framework for consolidated financial statements]. Mezhdunarodnyi bukhgalterskii uchet = International Accounting, 2015, vol. 18, iss. 39, pp. 2-26. URL: https://cyberleninka.ru/article/n/kontseptualnaya-osnova-konsolidirovannoy-finansovoyotchetnosti (In Russ.)

\section{Conflict-of-interest notification}

We, the authors of this article, bindingly and explicitly declare of the partial and total lack of actual or potential conflict of interest with any other third party whatsoever, which may arise as a result of the publication of this article. This statement relates to the study, data collection and interpretation, writing and preparation of the article, and the decision to submit the manuscript for publication. 